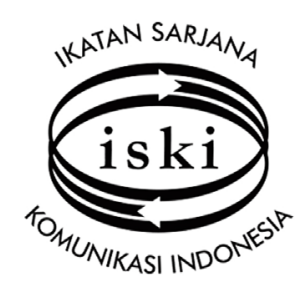

Jurnal Komunikasi ISKI, Vol. II (02), 2017. 65-70

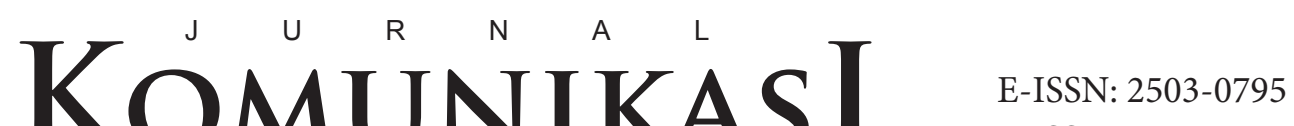 \\ KOMUNIKASI RABS
}

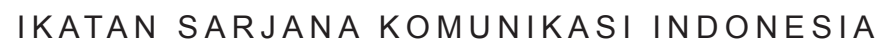

\section{Instagram Usage by Barstrad Community in Bandung City - West Java}

\author{
http://dx.doi.org/10.25008/jkiski.v2i2.104 \\ Gumgum Gumilar'; Ika Merdekawati Kusmayadi ${ }^{2}$ \\ ${ }^{1,2}$ Department of Journalism, Faculty of Communication Sciences, Padjadjaran University \\ Jl. Hegarmanah, Jatingor, Sumedang - Indonesia \\ 1'gumgum.gumilar@unpad.ac.id; 2i.m.kusmayadi@unpad.ac.id
}

\begin{abstract}
This study aims to collect qualitative data on Instagram Usage by Community of Bandung Street Workout Addict (Barstrad) in Bandung City, West Java. This study is applied descriptive method and collecting the data through depth interview and observation. The informant of this research is the founder Bastard community. The result shows that Instagram has significant role in developing of Barstard community, especially in terms of spreading out of street workout in Bandung City. Instagram is managed with a certain concept by informing the main activities, workout menus, schedules, and others as well. Instagram gives a huge impact on the increasing number of members who join in. Most of the member community are from Instagram followers that also make this community more well recognized and attracts sponsor in order to be a kind of sustainable community.
\end{abstract}

Keywords: Barstard, Bandung, Community, Instagram, Streetworkout

\begin{abstract}
Abstrak
Penelitian ini bertujuan mengumpulkan data kualitatif mengenai Pemanfaatan Instagram oleh Komunitas Bandung Street Workout Addict (Barstard) di Kota Bandung, Jawa Barat. Metode yang digunakan adalah deskriptif dengan informan penelitian meliputi pengelola, admin atau pencetus komunitas. Data diperoleh melalui wawancara mendalam dan observasi. Hasil Penelitian memperlihatkan instagram penting dalam pengembangan komunitas Barstard khususnya menyebarluaskan olah raga street workout di Kota Bandung. Instagram dikelola dengan konsep untuk menginformasikan kegiatan-kegiatan rutin, menu latihan rutin, jadwal latihan, dan contoh bentuk latihan. Instagram memberikan dampak besar terhadap peningkatan jumlah peserta latihan. Sebagian besar peserta latihan berasal dari follower instagram, selain itu instagram juga menjadikan komunitas ini semakin dikenal dan menarik minat sponsor yang berguna untuk keberlangsungan komunitas.
\end{abstract}

Kata Kunci: Barstard, Bandung Komunitas, Streetworkout 


\section{Introduction}

Internet user in Indonesia is increasing every year. Indonesian Internet Service Provider Association (APJII) recorded that the internet use in Indonesia reached 88.1 million users in 2015. APJII also reported that most of internet users are based in Java and Bali totaling 52 million. Its data can be seen in the following figure:

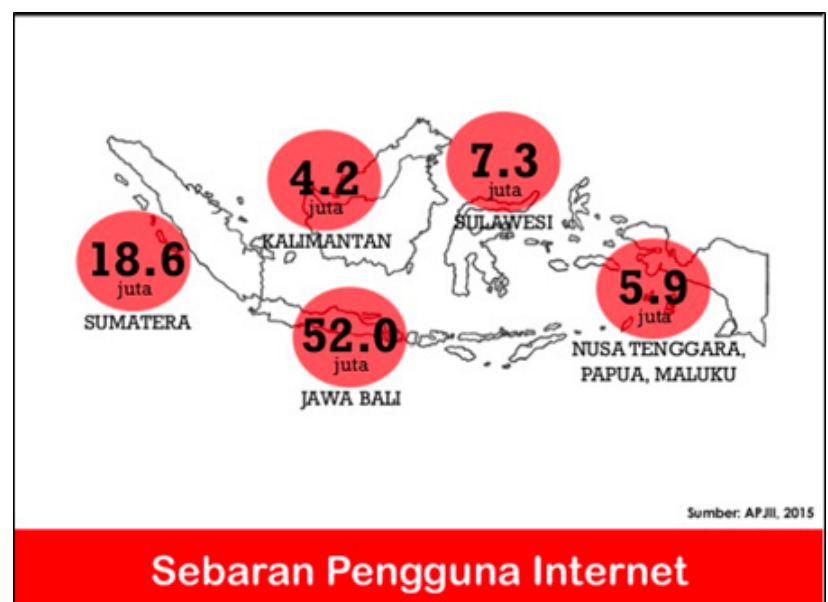

Figure 1. Distribution of Internet Users in Indonesia (source: APJII 2015)

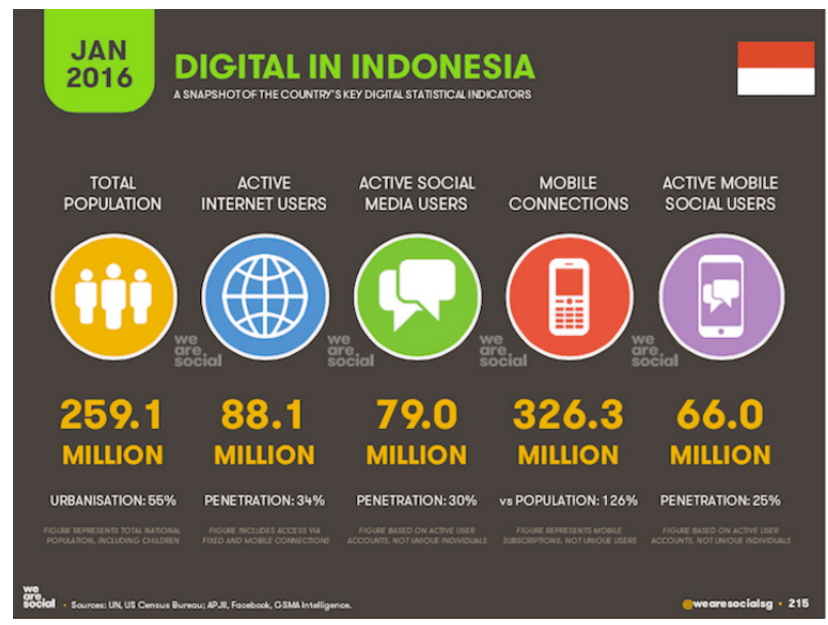

Figure 2: Internet user data in Indonesia (source: wearesocial.com)
The internet use data issued by APJII is similar with the data from "We Are Social", a social marketing agency in Singapore recorded that internet users in Indonesia was 88.1 million in early 2016 -34 percent of its total population. We are social also noted that the mobile internet users in Indonesia has reached to 64,1 million or approximately $25 \%$ of the total population. From all total of internet users in Indonesia, most of them were active social media users. In Indonesia there has been reaching 79 million social media users by utilizing internet mobile or mobile phone (Rachmiatie, 2016).

Based on the mentioned data above, social media usage becomes the biggest access of the internet users in Indonesia which is very diverse. According to Nasrullah (2015) social media is an internet medium that enabling internet users to represent their self, interact with others, share things, working together, communicate with other users, and creates social bonded virtually. As its function, media makes people able to change information with other people who is the user of that media. However, in developing time, social media is not only use as personal interest. Now, social media has been expanding its usage to other aspects,

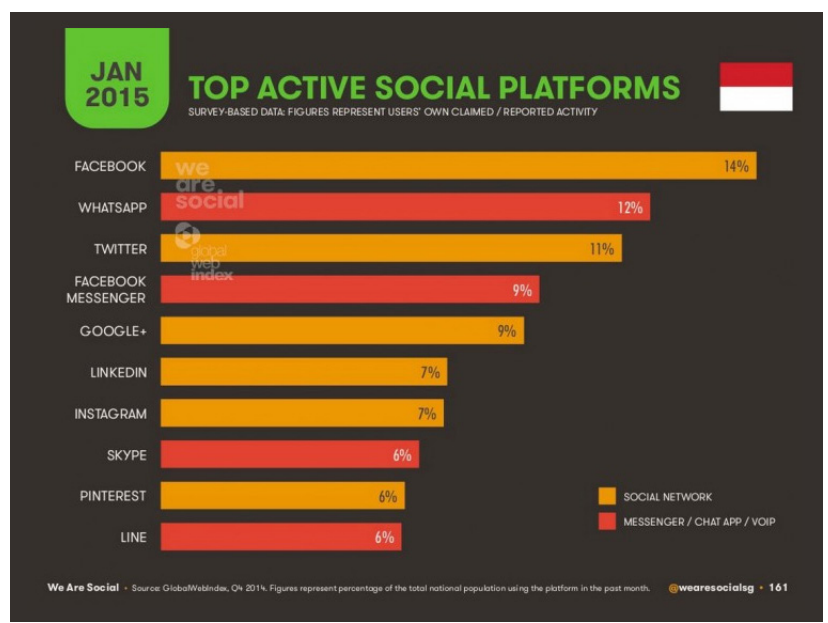

Figure 3: Social Media Users in Indonesia (Source: wearesocial.com) 
such as creates its own communities.

Sport communities now, are really hype and developing in all area including Bandung. By utilizing social media, these sport communities embrace people especially the youth to apply healthy life by doing a regular exercise routinely. It becomes unique, because this community is built in the online world (cyber world) relying on internet connection through social media, therefore this community can be quickly spread and accepted by the society.

This community utilizes social media Instagram as their main platform in disseminating information for its community. According to wearesocial.com Instagram, users in Indonesia increased 10\% in 2015. Every year Instagram enhances their features, such as Camera, Editor, Tag and Hashtag, Caption and is integrated with others social network namely Facebook or Twitter, making it easier for social media users to expand their information networks.

This paper portrays the data on Instagram Usage by the Barstrad Community in developing StreetWorkOut sports for the society, especially the youth in Bandung City.

\section{Theoretical Framework}

Social media now is still a term that contains diverse meaning and unidentified definition. Safko for example, explained that social media refers to a series of activities, practices and behaviors among the communities who gather online to share various information, knowledge and opinion utilized conversational media. Media conversational itself is a web-based application that makes the production and transmission of content in words, pictures, videos, and audio become possible and easy to be accessed (Safko \& Brake, 2009).

Nasrullah (2015) defines social media as a medium on the internet that allows users to represent themselves as well as interact, cooperate, share, communicate with other users, and also form a virtual social bond.

Social media phenomenon is a part of social software trend web 2.0 or user generated content which then evolves into various variants or genres, such as blogs, wikis, media-sharing sites, social network sites, social bookmarking, virtual worlds, microblogging sites, and more. These genres then are collected in an umbrella concept and as we called social media. The term of social media now is often used in academic field, seminar and publication, either its popular or scientific publication to replace the term of social network and social software. However, in academic field some, people still use term of Computer Mediated Communication (CMC) as a refer to social media (Boyd \& Ellison, 2010). Boyd itself uses the term of social media and social network sites (SNS) alternately to portray similar concept.

Social media appears in new media and always receives warm welcome from the internet users. Social media allows people to be able to exchange information with anyone who is the users of the media. In social media, according to Wright and Hinson (2009) the users can do the things as follows: (1) Publishing or showing creative digital contents, personal contents or pages that can be determined by ourselves, whether it is made by yourselves or others; (2) Providing and having real-time online features, a place where we can have a dialogue in the form of direct conversation or comment with other users; (3) Making some changes, fixes or improvements of the page that can be done by ourselves being suitable with our taste or desire, and then we can claim as the actual content.

Nasrullah (2015) acknowledges the characteristic of social media:

(1) Network. The character of social media is to form network between its users regardless the users know each other in the offline world. However, the present of social media gives a medium for the users to connect technologically. Networks formed among users ultimately have formed a community or society consciously or not that could bring up the values existing in the community as a characteristic of society in social theories;

(2) Information. Information here becomes an important entity of social media. Unlike other media on the internet, social media users create their identity representation, produce content, and interact based on information they received. Information here plays as a commodity in information society. Because it is produced, exchanged, and consumed that make information as a value commodity into a new form of capitalism;

(3) Archive. For social media users, archive is assigned as a character which explains that information is stored and accessible at any time through any device. Information will remain stored and even easily accessible;

(4) Interactivity. The basic character from social media is formed networking among the users. Its 
network does not only extend to friends or followers relationship in the internet but it also build the interaction between the users;

(5) Simulation of Society. Social media has a character as a medium of community or society in the virtual world. Like a public or a state, social media also has rules and ethics that are attached among users;

(6) User Generated Content. User Generated Content is a symbolic relation in the new media culture that give users an opportunities and discretions to participate. This situation is clearly different, compared with traditional media whose its audience is limited to be a passive objects or targets in the distribution of messages. New media including social media, offers new technologies that enable audience to put into archive, annotate, customize and re-circulate the media content and bring it to the state of do-ityourself media production.

\section{Material and Methodology}

The approach of this study is qualitative research. According to Creswell (2013), qualitative research is a depth process that refers to methodological traditions to explore human problems. Researchers build a complex interaction, an overview off whole reality, content analysis, informant reports, and all data that are obtained in the field.

Creswell says that qualitative approach is an approach to build knowledge statement based on constructive perspective, such as meaning that is derived from people experience, social and historical values, in order to form a theory or a certain knowledge pattern based on participatory perspective which is difficult to be processed.

The data is collected through depth interview with the founder and coordinator of the Barstard community who manages Instagram, observation and literature study related to Barstard community and Streetworkout.

\section{Result and Discussion}

Community Bandung Streetoworkout Addict (Barstrad) is a community that develops outdoor sports. Streetworkout is a form of calisthenics and bodyweight exercise that is usually done in open space (public park). Calisthenics is a form exercise consisting of simple and rhythmic movements that are generally performed without equipment usage, while bodyweight exercise is a strength exercise that does not require additional weight, practically it is fo- cus on body weight as a tool for exercise. According to Ilham, the coordinator of Barstard Community, calisthenics have various form of exercise and one form that is developed by the community is called Pull Up Bar.

Barstrad community was built in 2013 by Herin and his four friends on the basis of curiosity of streetworkout that highlighted on body weight training to shape the body. In the beginning of creating the community, this community was originally named Indobarian Bandung. However, its system inside of the community was changed after eight months with the emergence of Barstrad. Since then, Barstard community utilizes Instagram as the main medium to communicate, although previously they had used twitter. They experienced that twitter has its limitations to post photos and videos, whereas Instagram is considered as more visual and complete as it is able to post photo, videos and text at one posting.

Ilham says that it is difficult to determine the exact number of Barstrad Community members as the nature of the community is an open community, therefore its member may decrease or even increase at any time. Barstard Community does not apply permanent membership nor attendance lists for the activities, everyone who is interested in this kind of exercise is welcome to participate by coming to the park directly because it has routine schedule in the afternoon up to evening daily.

The number of active members can be seen from members who participate or come and join daily routine activities. Barstard Community held daily exercises by dividing the member into four groups -- each group consists of 35-60 people. The number of member who comes to exercise can change every day and it is difficult to know a definite data of the members. The average number of Barstard Community member is approximately 250 people. Compared with other Instagram followers in Bandung city only having 2.000 followers or even less, Barstard community has

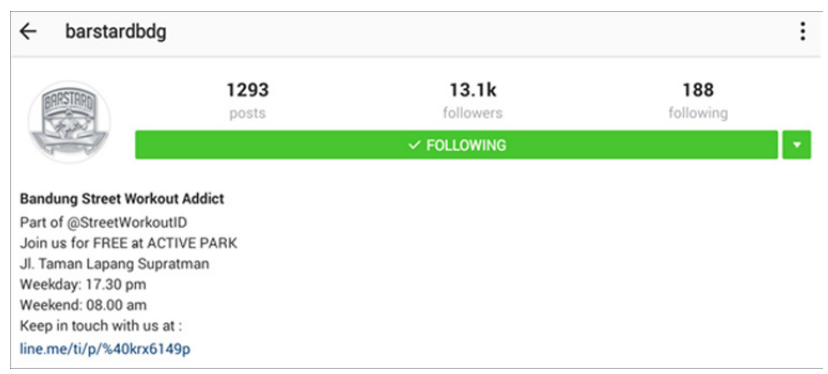

Figure 4. Barstard Community Instagram Account 
Table 1. The Number of Followers IntagramStreetworkout Community in Bandung City

\begin{tabular}{|l|l|l|}
\hline Number & Community & Followers Number \\
\hline 1 & Barstard & 13.100 \\
\hline 2 & Freeletics & 2101 \\
\hline 3 & Indorunnersbdg & 1750 \\
\hline
\end{tabular}

more than 10.000 followers.

Barstard community has the highest number of followers compared to similar communities in Bandung city which is only 13 thousand followers. The Barstard community Instagram account is only managed by one admin with a clear concept in terms of posting information on their Instagram. The concept can be seen from the posting schedule and the information posted. They post any information every day, at least twice a day, before and after routine exercise.

The idea of administrator produces information to be posted on Instagram emerges from various of sources: first, the admin documents directly on the exercise activities; second, information of the exercise schedule; third, daily exercise menu (daily workout) that can be done anywhere; fourth, re-post the follower's Instagram; and the fifth the content based on the member needs.

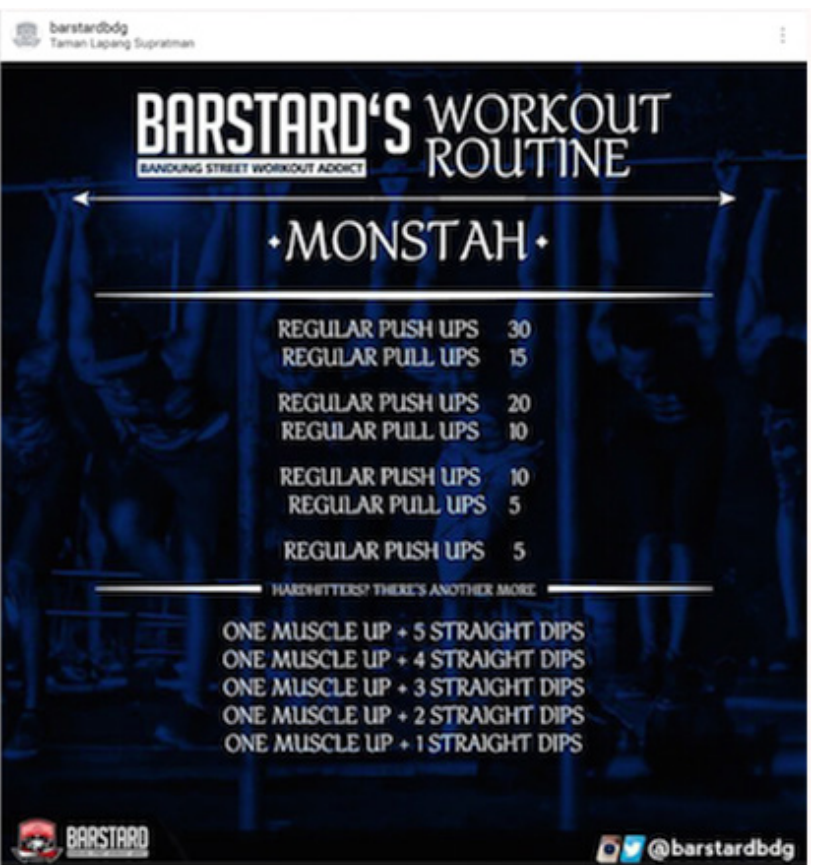

Figure 5. Example of Routine Exercise Menu

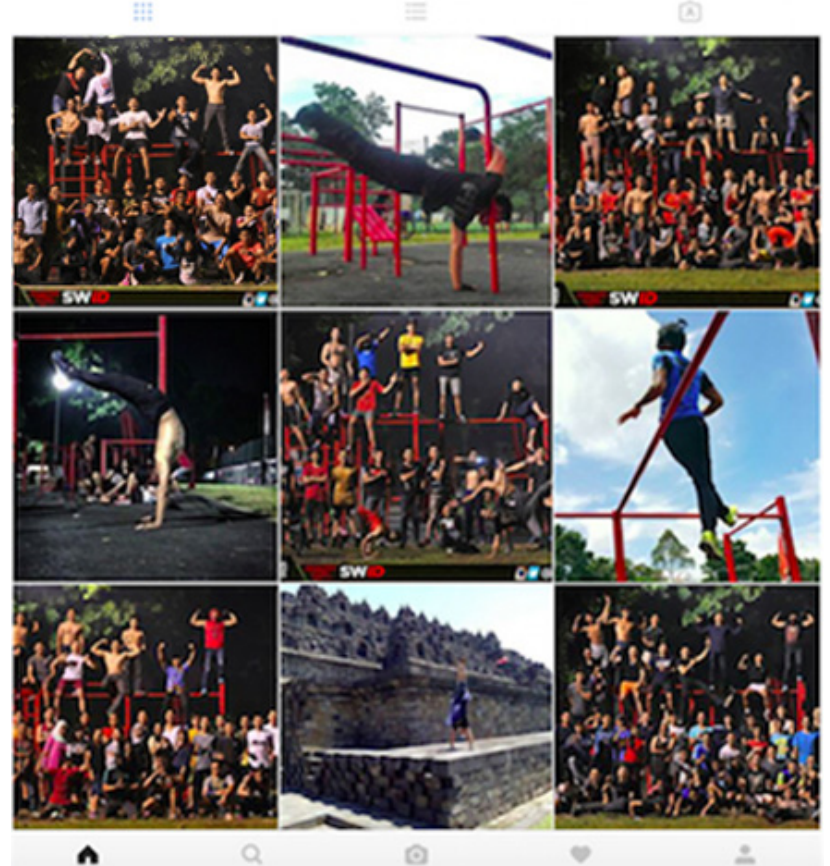

Figure 6. Example of Information Activities in the form of Picture

Routine activities managed by the community are divided based on basic, intermediate, and advance levels. This is done by following the development of the community where at the beginning of its commencement, it was only followed by few members with the same level and tried to develop tricks in this exercise and did several of activities to the next level. But now, many new members who do not have knowledge or understanding about street workout, they start from scratching. In addition, the information that is posted on Instagram has to meet the needs of any level in doing this exercise.

Social media usage especially Instagram by the Barstard Community gives a positive impact, such as: (1) Instagram causes a significant increase in the number of exercise members, which most of the members are Instagram followers; (2) disseminating information about streetworkout that can be used as an alternative exercise by the young people and workers, who usually do not have much time to do exercise; (3) developing healthy lifestyles among young people.

In addition, Instagram also gives a financial impact. Information on Instagram now makes Barstard community knows and attracts more sponsor's attentions. As a result, Barstard community now has had sponsors and attracted the attention of third parties both from government and private parties. 


\section{Conclusion}

Instagram is used by The Barstard Community as a medium to communicate and deliver the information about street workout, and also inform other activities that has been done by the community especially information on the routine exercises. The Instagram usage gives a significant impact, particularly in terms of the increasing number of its member who join the exercise, and also for the survival of the community by the sponsor endorsement.

\section{References}

Boyd, D., \& Ellison, N. (2010). Social Network Sites: Definition, History, and Scholarship. IEEE Engineering Management Review, 3(38), 16-31.

Creswell, J. W. (2013). Research Design: Qualitative, Quantitative, and Mixed Methods Approaches. Sage Publications.

Nasrullah, R. (2015). Media Sosial Perspektif Komunikasi, Budaya, dan Sosioteknologi. Bandung: Simbiosa Rekatama Media.

Rachmiatie, A. (2016). Membangun Kecerdasan Informasi dalam Peneguhan Karakter Bangsa. Jurnal Komunikasi Ikatan Sarjana Komunikasi Indonesia, 1(2), 114-121.

Safko, L., \& Brake, D. (2009). The Social Media Bible. Execu Go Media.

Wright, D. K., \& Hinson, M. D. (2009). An Analysis of the Increasing Impact of Social and Other New Media on Public Relations Practice. In 12th Annual International Public Relations Research Conference, Miami, Florida. 